\title{
Re: Video-assisted left inguinal lymphadenectomy for penile cancer
}

\author{
Alexandre Stievano Carlos, Leonardo Oliveira Reis, Marcos Tobias-Machado \\ Department of Urology, ABC Medical School (ASC, MTM), Santo André and Department of Surgery \\ (Urology), School of Medical Sciences, University of Campinas, UNICAMP (LOR), SP, Brazil
}

Int Braz J Urol. Vol. 38(2): 289-290, March - April, 2012;

http://brazjurol.com.br/march_april_2012/Nideo_Britto_289_290.htm

\section{To the editor,}

The concept of endoscopic inguinal dissection for penile cancer was proposed by Bishoff et al. from San Antonio, Texas, USA in 2003 with the dissection of 2 cadaveric models. After some modifications, the first case in clinical scenario was successfully operated at ABC Medical School, São Paulo, Brazil in 2003 by Tobias-Machado et al which nominate their procedure as VEIL (video endoscopic inguinal lymphadenectomy) (1).

In order to achieve the maximum benefits of the minimally invasive approach, regarding morbidity reduction, the $\mathrm{ABC}$ Medical School technique was based in 10 major steps and we would like to emphasize 3 of them: distal lymphatic tissue ligation at the femoral triangle vertex, proximal control of visualized lymphatics with clips and ligation of the proximal portion of the lymphatic tissue at the deep portion of the femoral channel (2). We are concerned about these issues because in the presented video no lymphatic clipage was documented, the tissue was sectioned using only monopolar electrocautery. This can increase the post-operative complications related to the lymphatic tissue, thereby reducing the benefits of minimally invasive procedure. It is fundamental to stress that no energy source (electric, ultrasonic, ligasure) can adequately seal lymphatic vessels. One other interesting observation is that monopolar energy can be used but control is needed when it is utilized near the skin to prevent an isquemic event. The present video demonstrates the dissection in the correct plane (under Scarpa's fascia) to maintain some fat under the skin.

A randomized comparison with open surgery in nonpalpable inguinal nodes patients showed a reduced overall complication rate of endoscopic technique (20 X 70\%) specially related to skin events ( 0 x 40\%) (3). The same number of nodes could be obtained comparing the approaches. Five year follow-up series showed cancer specific survival of 100\% for negative inguinal nodes and $80 \%$ for positive nodes suggesting that VEIL is oncological effective (4).

Veil is having a growing international acceptance but experience is yet small. Actually about 20 centers around the world performed the endoscopic procedure with success and very similar results. Some centers are applying endoscopic surgery for other tumors as melanoma, vulvar and anal cancers. Actual results lead us to think that this technique has the potential to reduce post-operative morbidity (2-6).

Nevertheless we would like to congratulate Britto et al who demonstrated the reproducibility of the method at the Federal University of Rio Grande do Norte, it could be consider especially important because VEIL can be of great value in a region which has a high incidence of penile cancer. 


\section{REFERENCES}

1. Tobias-Machado M, Tavares A, Molina WR Jr, Zambon JP, Medina JA, Forseto PH Jr, et al.: Video endoscopic inguinal lymphadenectomy (VEIL): initial case report and comparison with open radical procedure. Arch Esp Urol. 2006; 59: 849-52.

2. Tobias-Machado M, Tavares A, Molina WR Jr, Forseto PH $\mathrm{Jr}$, Juliano RV, Wroclawski ER: Video endoscopic inguinal lymphadenectomy (VEIL): minimally invasive resection of inguinal lymph nodes. Int Braz J Urol. 2006; 32: 316-21.

3. Tobias-Machado M, Tavares A, Ornellas AA, Molina WR Jr, Juliano RV, Wroclawski ER: Video endoscopic inguinal lymphadenectomy: a new minimally invasive procedure for radical management of inguinal nodes in patients with penile squamous cell carcinoma. J Urol. 2007; 177: 953-7; discussion 958.
4. Tobias-Machado M, Tavares A, Silva MN, Molina WR Jr, Forseto PH, Juliano RV, et al.: Can video endoscopic inguinal lymphadenectomy achieve a lower morbidity than open lymph node dissection in penile cancer patients? J Endourol. 2008; 22: 1687-91.

5. Sotelo R, Sánchez-Salas R, Carmona 0, Garcia A, Mariano $M$, Neiva $G$, et al.: Endoscopic lymphadenectomy for penile carcinoma. J Endourol. 2007 Apr;21(4):364-7; discussion 367.

6. Master V, Ogan K, Kooby D, Hsiao W, Delman K: Leg endoscopic groin lymphadenectomy (LEG procedure): stepby-step approach to a straightforward technique. Eur Urol. 2009; 56: 821-8.

Correspondence address:

Dr. Alexandre Stievano Carlos, Department of Urology, ABC Medical School, Santo André, Rua Cantagalo 612 / 61 São Paulo, SP, Brazil Fax +55 11 2093-7434

E-mail:ale_carlos@uol.com.br 